\title{
Pathological Vaginal Discharge among Pregnant Women: Pattern of Occurrence and Association in a Population-Based Survey
}

\author{
Tânia Maria M. V. da Fonseca, ${ }^{1}$ Juraci A. Cesar, ${ }^{2}$ \\ Raúl A. Mendoza-Sassi, ${ }^{2}$ and Elisabeth B. Schmidt ${ }^{3}$ \\ ${ }^{1}$ Programa de Pós-Graduação em Educação em Ciências: Química da Vida e Saúde, Universidade Federal do Rio Grande, \\ Rua Dr. Nascimento 737, 96200-300 Rio Grande, RS, Brazil \\ ${ }^{2}$ Divisão de População \& Saúde, Universidade Federal do Rio Grande Área Acadêmica do Hospital Universitário da FURG, \\ Rua Gen. Osório S/N. 96200-190 Rio Grande, RS, Brazil \\ ${ }^{3}$ Programa de Pós-Graduação em Educação em Ciências: Química da Vida e Saúde, Universidade Federal do Rio Grande, \\ Avenida Itália, km 8, Campus Carreiros, 96203-900 Rio Grande, RS, Brazil \\ Correspondence should be addressed to Tânia Maria M. V. da Fonseca; tania.fonseca@vetorial.net
}

Received 29 January 2013; Revised 9 May 2013; Accepted 18 May 2013

Academic Editor: Everett Magann

Copyright (C) 2013 Tânia Maria M. V. da Fonseca et al. This is an open access article distributed under the Creative Commons Attribution License, which permits unrestricted use, distribution, and reproduction in any medium, provided the original work is properly cited.

\begin{abstract}
This study aimed to assess the prevalence of pathological vaginal discharge and to describe risk factors associated with pregnant women. All women living in the city of Rio Grande, Southern Brazil, who gave birth in 2010 were included in the study. A standardized questionnaire was administered to collect information on demographic, reproductive, and health-related factors and morbidity during pregnancy. The chi-square test was used to compare proportions, and multivariate Poisson regression with robust variance was performed. Of the 2,395 women studied, $43 \%$ had pathological vaginal discharge during pregnancy. The adjusted analysis showed that younger women of lower socioeconomic condition, those with a past history of abortion, vaginal discharge in a previous pregnancy, and treated for depression, anemia, and urinary tract infection during their current pregnancy, were more likely to have pathological vaginal discharge. Vaginal discharge during pregnancy was highly prevalent in the sample studied calling for proper risk factor management at the primary care level.
\end{abstract}

\section{Introduction}

Vaginal discharge is a common gynecological condition among women of childbearing age that frequently requires care affecting about one-third of all women and half of pregnant women [1-3].

Pathological vaginal discharge can cause serious harm to pregnant women and their children including prematurity, low birth weight, chorioamnionitis, postpartum endometritis, and postcesarean wound infection [4-6]. It is the second leading cause of lost years of healthy life for women aged 15 to 49 . It is also a facilitator of human immunodeficiency virus (HIV) infection for the virus can gain entry into cells and for it evidences that these women are having unprotected sex [7].
Vaginal discharge is normal in women in their childbearing years. It derives from physiological secretion of cervical and Bartholin's glands and desquamation of vaginal epithelial cells resulting from bacterial action in the vagina. When abnormal vaginal discharge is more abundant and has an unpleasant odor, it is usually accompanied by vulval or vaginal itching, dysuria, and/or dyspareunia $[1,2]$. Studies carried out in developing countries demonstrated that vaginal discharge is caused by sexually transmitted infections (STIs) in up to $90 \%$ of cases $[8,9]$.

During pregnancy genital mucosa becomes thinner and has greater surface area making pregnant women more susceptible to infections [10, 11]. In addition, in Brazil, women in general lack knowledge on this condition, they do not 
TABLE 1: Hierarchical model of analysis for factors associated with the occurrence of pathological vaginal discharge.

\begin{tabular}{|c|c|c|c|}
\hline Level & & \multicolumn{2}{|l|}{ Variables } \\
\hline \multirow{2}{*}{ I } & Demographic: & \multicolumn{2}{|l|}{ Socioeconomic: } \\
\hline & Maternal age, skin color, and marital status & \multicolumn{2}{|l|}{ Maternal education and household asset index } \\
\hline \multirow{2}{*}{ II } & Behavioral characteristics: & \multicolumn{2}{|l|}{ Obstetric history: } \\
\hline & Smoking & \multicolumn{2}{|c|}{ Parity, previous abortion, and planned pregnancy } \\
\hline \multirow{2}{*}{ III } & Prior use of contraceptive method: & History of morbidities: & Current pregnancy care: \\
\hline & Oral contraceptives & Vaginal discharge in a previous pregnancy & Prenatal care visits \\
\hline Outcome & Patho & ical vaginal discharge during pregnancy & \\
\hline
\end{tabular}

recognize it as being important, and they are not able to follow health providers' guidance to practice good hygiene habits $[10,12]$. Brazilian women are also known to use condoms exclusively as a birth control method but not for STI prevention $[12,13]$.

This study was carried out in Rio Grande, Southern Brazil. This municipality is the only seaport city in the state of Rio Grande do Sul. It has a population of around 200,000 inhabitants (IBGE, 2010) over $2.900 \mathrm{~km}^{2}$ and its diverse economy is primarily based on port activities. The city's per capita gross domestic product (GDP) is approximately R $\$$ 32,000. Infant mortality rate of Rio Grande in 2010 was 11.4 per 1,000 live births (2011) [14]. At the time of this study, the city had two hospitals with a total capacity of 600 beds, of which 56 were obstetric beds, and an average of 2,500 deliveries a year [14].

This study aimed to assess the prevalence of pathological vaginal discharge and to describe risk factors associated with pregnant women.

\section{Methods}

A cross-sectional design was used to assess women who gave birth; they were interviewed only once while staying at the maternity wards. This study design was selected because it allows to assess the prevalence of the condition and/or frequent events and to collect information from a large number of individuals in a short time [15].

A precoded questionnaire was developed to collect information on place of residence, demographic characteristics, maternal reproductive history, socioeconomic condition, household assets, housing and sanitation conditions, care during pregnancy and childbirth, and complications during pregnancy. Although most variables are self-explanatory, additional clarification is required for some of them: skin color: categorized by the interviewer as white, mixed, and black; household income: the income of all household members in the month preceding the interview; household asset index: household ownership of goods including vacuum cleaner, washing machine, DVD player, refrigerator, freezer, microwave oven, personal computer, telephone, radio, TV set, motor vehicle, air conditioner; and having a hired household helper. This variable also included maternal education and household income. Different components were generated and the first one was used to create a continuous score that included all variables that make direct contributions. This component had an eigenvalue of 5.18 and explained $32 \%$ of the total variance. This variable was subsequently divided into tertiles for the analyses: maternal smoking: if smoked at least once in the six months prior to pregnancy; alcohol use: if used alcohol during pregnancy; occurrence of comorbidities such as anemia, depression and arterial hypertension, among others: affirmative answer if present; perceived abnormal vaginal discharge (outcome): reported vaginal discharge associated with at least one of the following symptoms including itching, dysuria, dyspareunia, odor, and nonwhite color.

Four interviewer candidates were trained for five consecutive days. At the end of training three of them were hired. A pilot study was conducted in the city's two maternity hospitals to test the study questionnaire and check for any issues regarding wording of questions. At this step at least four complete questionnaires were administered by each interviewer. All instruments used in the study were provided with a manual with detailed instructions for completion.

Interviewers coded the complete questionnaires at the end of each data collection day and handed them to the study staff by the end of each week. Open questions were also coded. All questionnaires were fully reviewed and entered in EpiData 3.1. Data was later moved to Stata 11.0 (Stata Corp., College Station, USA) for consistency analysis, categorization of variables, and data analysis.

An analysis was first performed to assess frequencies and consistency of independent variables and the outcome (occurrence of pathological vaginal discharge). Data were entered in a database for labeling and construction of derived variables.

A multivariate analysis was conducted in accordance with a predefined hierarchical model (Table 1). In this model some variables were considered as determinants. The variables included in the first level may have a direct contribution to the outcome (e.g., perceived pathological vaginal discharge during pregnancy) or may have a contribution through variables included in other levels, that is, indirectly contributing to a symptom. Measures of disease occurrence and effect were prevalence and prevalence ratio, respectively. Prevalence ratios (PR) and their crude and adjusted 95\% confidence intervals (95\% CI) were calculated using Poisson regression with robust adjustment of variance. Variables with $P<0.20$ were included in the adjusted model to control for potential confounders [16]. 
The variables included in the first level of the hierarchical model were maternal age, skin color, marital status, maternal education, and socioeconomic condition. In the second level the variables smoking, parity, abortion, and planned pregnancy were included. And in the third level, use of oral contraceptives, prenatal visits, and vaginal discharge in the previous pregnancy were included. To investigate comorbidities associated with the prevalence of vaginal discharge, potential confounding variables that were associated $(P<$ $0.20)$ with the outcome were included. A $95 \%$ significance level was used for two-sided tests. In this analysis model, variables at an upper level than the variable in question were considered potential confounders of the outcome while those variables in lower levels were considered potential mediators of the association. Those variables selected at a given level remained in the model and were considered potential risk factors for the outcome even if they lost their statistical significance with the inclusion of lower-level variables.

For quality control $5 \%$ of the interviews were repeated. Mothers were randomly selected and home interviews were conducted using a shortened version of the study questionnaire. All respondents signed an informed consent and respondent confidentiality was ensured.

The present study was approved by the Research Ethics Committees of the Universidade Federal do Rio Grande (FURG) (Protocol no. 23116006258/2009-64-53/2009) and of the Santa Casa de Misericórdia de Rio Grande (Protocol no. 009/2009).

\section{Results}

Of 2,464 pregnant women living in the city of Rio Grande who gave birth in 2010, 2,395 (97.25\%) were included in the study.

The prevalence of vaginal discharge during pregnancy was 43\% (95\% CI 40.9; 44.9) among all women studied. About $20 \%$ were adolescents (younger than 20), 68\% were whiteskinned, $83 \%$ lived with a partner, $55 \%$ had nine or more years of schooling, $26 \%$ were smokers, $44 \%$ were primiparous, $14 \%$ reported previous abortion, 36\% planned pregnancy, $80 \%$ attended six or more prenatal visits, and $11 \%$ reported pathological vaginal discharge in a previous pregnancy. Only $53 \%$ of women who reported the occurrence of vaginal discharge underwent treatment for the symptom.

Table 2 shows the prevalence of pathological vaginal discharge during pregnancy according to the category of the variable included in the model and crude and adjusted PRs. The prevalence of pathological vaginal discharge ranged from $32 \%$ in women aged 30 and older to $82 \%$ in those who reported pathological vaginal discharge in a previous pregnancy.

The crude analysis showed that pathological vaginal discharge during pregnancy was significantly associated with the following variables: maternal age; living with a partner; household asset index; parity; vaginal discharge in a previous pregnancy; and diabetes, depression, threatened premature labor, urinary infection, and hospitalization during the current pregnancy.
A protective effect of maternal age on the likelihood of occurrence of pathological vaginal discharge was found after adjustment. A PR of 0.72 (95\% CI 0.63 ; 0.82) was found in women aged 30 and more compared to those aged 20 to 29 years. Women in the lower wealth tertile showed a PR of $1.22(1.07 ; 1.39)$ compared to those in the highest tertile. Those who reported a previous abortion and pathological vaginal discharge in a previous pregnancy showed a PR of $1.20(1.05 ; 1.38)$ and $2.26(2.02 ; 2.54)$, respectively, compared to other women. A PR of 1.36 (1.20 to 1.54) and 1.26 (1.15; 1.38) was found in women treated for depression and anemia, respectively, compared to all other women. A PR of 1.27 (1.11; 1.45) was found for threatened premature labor. Finally, a PR of $1.49(1.36 ; 1.63)$ and $1.24(1.10 ; 1.41)$, respectively, was observed on those who had urinary tract infection or were hospitalized.

\section{Discussion}

Vaginal discharge affected $43 \%$ of the women studied. The main risk factors associated were young age, low socioeconomic condition, vaginal discharge in a previous pregnancy, depression, anemia, threatened premature labor, urinary infection, and hospitalization in the current pregnancy.

A higher prevalence of vaginal discharge during pregnancy was seen in women younger than 20 (the prevalence ratio was about $50 \%$ higher). A number of studies have reported higher prevalence of vaginal discharge symptoms and STDs in younger women $[17,18]$. In addition to their greater biological vulnerability, adolescents are more susceptible to engaging in risky behaviors and to acquiring STDs. This is a widely known phenomenon in the context of STDs mostly due to the fact that teenagers believe that love will protect them against STDs, which partly explains the spread of these infections among women with a steady partner [12].

This study found higher rates of vaginal discharge during pregnancy among poor women. Similar results were reported in a study conducted in the same city in 2007 [18].

Reporting vaginal discharge in a previous pregnancy was the strongest predictor of vaginal discharge in the current pregnancy showing a PR twice as high (PR 2.26, 2.02; 2.54). This association was also demonstrated in a 2007 study [17]. It is possible that the previous occurrence and inadequate handling by health providers facilitate the installation of a new infectious process or, by the presence of the same risk factors, this outcome recurs in the next pregnancy. Possibly, it is due to the fact that health providers do not investigate a potential link between the complaint of vaginal discharge and STIs and their mode of transmission, and thus they are not properly managed. The differentiated approach to patients with symptoms suggestive of STIs by health providers increases the probability of treatment of the sexual partner and the return to the service for the control of healing, aspects that are important to break the chain of transmission of STIs, and the recurrence of symptoms $[19,20]$.

This study found that vaginal discharge was associated with depression; it was seen in 55\% of women who reported having depression during pregnancy. Depression rates are 
TABLE 2: Crude and adjusted analysis of factors associated with the prevalence of pathological vaginal discharge during pregnancy. Rio Grande, Brazil, $2010(N=2,395)$.

\begin{tabular}{|c|c|c|c|c|c|c|}
\hline \multirow[b]{2}{*}{ Level } & \multirow[b]{2}{*}{ Variable } & \multirow[b]{2}{*}{ Vaginal discharge (\%) } & \multicolumn{2}{|c|}{ Crude analysis } & \multicolumn{2}{|c|}{ Adjusted analysis } \\
\hline & & & $\begin{array}{l}\text { Prevalence ratio } \\
\quad(95 \% \mathrm{CI})\end{array}$ & $P$ value & $\begin{array}{l}\text { Prevalence ratio } \\
\quad(95 \% \mathrm{CI})\end{array}$ & $P$ value \\
\hline \multirow{20}{*}{$\mathrm{I}$} & Age (years) & & & $<0.001$ & & $<0.001^{*}$ \\
\hline & Up to 19 & 49.9 & $1.08(0.96 ; 1.20)$ & & $1.05(0.94 ; 1.18)$ & \\
\hline & $20-29$ & 46.3 & 1.00 & & 1.00 & \\
\hline & 30 or more & 32.1 & $0.70(0.61 ; 0.78)$ & & $0.72(0.63 ; 0.82)$ & \\
\hline & Skin color & & & 0.44 & & 0.44 \\
\hline & White & 42.5 & 1.00 & & 1.00 & \\
\hline & Mixed & 45.2 & $1.06(0.95 ; 1.19)$ & & $1.02(0.91 ; 1.14)$ & \\
\hline & Black & 40.8 & $0.96(0.82 ; 1.13)$ & & $0.91(0.77 ; 1.07)$ & \\
\hline & Living with a partner & & & 0.01 & & 0.11 \\
\hline & No & 48.8 & $1.18(1.05 ; 1.31)$ & & $1.10(0.98 ; 1.23)$ & \\
\hline & Yes & 41.7 & 1.00 & & 1.00 & \\
\hline & Education (years of schooling) & & & 0.17 & & 0.78 \\
\hline & $0-4$ & 40.3 & $1.09(0.86 ; 1.38)$ & & $0.93(0.72 ; 1.19)$ & \\
\hline & $5-8$ & 44.8 & $1.21(1.01 ; 1.44)$ & & $0.97(0.80 ; 1.18)$ & \\
\hline & $9-11$ & 43.1 & $1.16(0.97 ; 1.38)$ & & $1.01(0.85 ; 1.22)$ & \\
\hline & 12 or more & 37.1 & 1.00 & & 1.00 & \\
\hline & Household asset index (tertiles) & & & $<0.001$ & & 0.004 \\
\hline & Poorest & 48.8 & $1.28(1.14 ; 1.44)$ & & $1.22(1.07 ; 1.39)$ & \\
\hline & Intermediate & 41.9 & $1.10(0.98 ; 1.24)$ & & $1.05(0.92 ; 1.19)$ & \\
\hline & Richest & 38.0 & 1.00 & & 1.00 & \\
\hline \multirow{18}{*}{ II } & $\begin{array}{l}\text { Smoking in the six months prior to } \\
\text { pregnancy }\end{array}$ & & & 0.48 & & 0.80 \\
\hline & No & 42.5 & 1.00 & & 1.00 & \\
\hline & Yes & 44.1 & $1.04(0.94 ; 1.15)$ & & $0.99(0.89 ; 1.10)$ & \\
\hline & Parity & & & 0.01 & & 0.02 \\
\hline & 0 & 45.4 & $1.22(1.07 ; 1.40)$ & & $1.20(1.02 ; 1.40)$ & \\
\hline & 1 & 38.4 & $1.03(0.86 ; 1.23)$ & & $1.02(0.85 ; 1.22)$ & \\
\hline & 2 & 45.6 & $1.22(1.05 ; 1.42)$ & & $1.22(1.05 ; 1.42)$ & \\
\hline & 3 and more & 37.2 & 1.00 & & 1.00 & \\
\hline & Abortion & & & 0.22 & & 0.01 \\
\hline & No & 42.4 & 1.00 & & 1.00 & \\
\hline & Yes & 45.9 & $1.08(0.95 ; 1.23)$ & & $1.20(1.05 ; 1.38)$ & \\
\hline & Planned pregnancy & & & 0.08 & & 0.28 \\
\hline & Yes & 40.1 & 1.00 & & 1.00 & \\
\hline & More or less & 41.7 & $1.04(0.87 ; 1.25)$ & & $1.01(0.85 ; 1.21)$ & \\
\hline & No & 44.8 & $1.12(1.01 ; 1.24)$ & & $1.09(0.98 ; 1.21)$ & \\
\hline & Oral contraceptives & & & 0.74 & & 0.41 \\
\hline & No & 43.7 & 1.00 & & 1.00 & \\
\hline & Yes & 42.7 & $0.98(0.86 ; 1.11)$ & & $1.06(0.93 ; 1.21)$ & \\
\hline
\end{tabular}


TABLe 2: Continued.

\begin{tabular}{|c|c|c|c|c|c|c|}
\hline \multirow[b]{2}{*}{ Level } & \multirow[b]{2}{*}{ Variable } & \multirow[b]{2}{*}{ Vaginal discharge (\%) } & \multicolumn{2}{|c|}{ Crude analysis } & \multicolumn{2}{|c|}{ Adjusted analysis } \\
\hline & & & $\begin{array}{c}\text { Prevalence ratio } \\
(95 \% \mathrm{CI})\end{array}$ & $P$ value & $\begin{array}{c}\text { Prevalence ratio } \\
(95 \% \mathrm{CI})\end{array}$ & $P$ value \\
\hline & At least 6 prenatal visits & & & 0.46 & & 0.61 \\
\hline & No & 44.9 & $1.04(0.93 ; 1.17)$ & & $0.97(0.86 ; 1.09)$ & \\
\hline & Yes & 43.0 & 1.00 & & 1.00 & \\
\hline & $\begin{array}{l}\text { Vaginal discharge in a previous } \\
\text { pregnancy }\end{array}$ & & & $<0.001$ & & $<0.001$ \\
\hline & No & 40.1 & 1.00 & & 1.00 & \\
\hline & Yes & 84.5 & $2.45(2.20 ; 2.73)$ & & $2.26(2.02 ; 2.54)$ & \\
\hline & High blood pressure & & & 0.61 & & 0.37 \\
\hline & No & 42.6 & 1.00 & & 1.00 & \\
\hline & Yes & 43.9 & $1.03(0.92 ; 1.16)$ & & $1.05(0.94 ; 1.18)$ & \\
\hline & Diabetes & & & 0.66 & & 0.39 \\
\hline & No & 42.8 & 1.00 & & 1.00 & \\
\hline & Yes & 45.3 & $1.06(0.82 ; 1.36)$ & & $1.11(0.87 ; 1.42)$ & \\
\hline & Depression & & & $<0.001$ & & $<0.001$ \\
\hline \multirow[t]{17}{*}{ III } & No & 41.4 & 1.00 & & 1.00 & \\
\hline & Yes & 55.5 & $1.34(1.19 ; 1.52)$ & & $1.36(1.20 ; 1.54)$ & \\
\hline & Anemia & & & $<0.001$ & & $<0.001$ \\
\hline & No & 38.3 & 1.00 & & 1.00 & \\
\hline & Yes & 49.3 & $1.29(1.17 ; 1.41)$ & & $1.26(1.15 ; 1.38)$ & \\
\hline & Threatened abortion & & & 0.13 & & 0.10 \\
\hline & No & 42.5 & 1.00 & & 1.00 & \\
\hline & Yes & 48.6 & $1.14(0.96 ; 1.36)$ & & $1.16(0.97 ; 1.38)$ & \\
\hline & Threatened premature labor & & & 0.002 & & $<0.001$ \\
\hline & No & 42.0 & 1.00 & & 1.00 & \\
\hline & Yes & 52.1 & $1.24(1.08 ; 1.42)$ & & $1.27(1.11 ; 1.45)$ & \\
\hline & Urinary infection & & & $<0.001$ & & $<0.001$ \\
\hline & No & 35.4 & 1.00 & & 1.00 & \\
\hline & Yes & 54.2 & $1.53(1.40 ; 1.68)$ & & $1.49(1.36 ; 1.63)$ & \\
\hline & Hospitalization & & & $<0.001$ & & 0.001 \\
\hline & No & 41.7 & 1.00 & & 1.00 & \\
\hline & Yes & 52.9 & $1.27(1.12 ; 1.44)$ & & $1.24(1.10 ; 1.41)$ & \\
\hline
\end{tabular}

*Adjustment for maternal age, marital status, socioeconomic condition, parity and previous abortion.

higher in women attending gynecological clinics, and qualitative studies have demonstrated a strong relationship between vaginal discharge, psychosomatic symptoms, and stress [21, 22].

Anemia was significantly associated with vaginal discharge during pregnancy. Half of the women who had anemia reported pathological vaginal discharge. This finding is corroborated by another study with pregnant women. The high prevalence of abnormal vaginal discharge in this population shows the need to examine this relationship in greater depth in order to prevent occurrence [23].

Threatened premature labor was significantly associated with pathological vaginal discharge during pregnancy. Just over half $(52 \%)$ of women who reported threat of preterm labor complained of vaginal discharge. In this study, premature labor occurred in $15 \%$ of the women studied. An infectious cause is seen in about $40 \%$ of cases of spontaneous premature labor $[24,25]$. STIs have been associated with adverse pregnancy outcomes including premature birth and low birth weight-both major determinants of infant morbidity and mortality especially in developing countries where neonatal intensive care is available only in very few centers $[6,25]$.

This study showed that urinary tract infection reported during pregnancy was strongly associated with vaginal discharge, a finding that is corroborated by other studies $[17,18]$. There is growing evidence supporting that genital infections during pregnancy increase the risk of urinary tract infection, 
which is a major risk factor for premature birth and a leading cause of neonatal death $[24,26]$. It clearly shows the importance of early diagnosis and appropriate management of vaginal discharge to reduce infant deaths.

Pathological vaginal discharge was highly prevalent in the population of women studied. Younger women of low socioeconomic condition with a history of several morbid conditions during pregnancy are more likely to have vaginal discharge. These results stress a need for proper management and treatment of vaginal discharge, and pregnant women should be educated on good hygiene habits and prevention. If not, this almost imperceptible though highly prevalent condition among pregnant women will continue to favor the development of more severe conditions that significantly contribute to increased infant mortality. There is an urgent need for intervention.

\section{Conflict of Interests}

None of the authors had financial or nonfinancial competing interests.

\section{References}

[1] P. Naud, J. C. Matos, L. S. Hammes, and V. Magno, "Secreção vaginal e prurido vulvar," in Medicina Ambulatorial: Condutas de Atenção Primária Baseada em Evidências, B. B. Duncan, M. I. Schmidt, and E. J. Giugliani, Eds., p. 46, Artmed, Porto Alegre, Brazil, 3rd edition, 2004.

[2] A. L. P. Amaral, H. C. Oliveira, L. F. P. Amaral, and M. A. P. Oliveira, "Corrimento genital," in Tratado de Ginecologia, $\mathrm{H}$. W. Halbe, Ed., pp. 501-511, Editora Roca, São Paulo, Brazil, 2nd edition, 1994.

[3] Ministério da Saúde (Brasil), Secretaria de Vigilância em Saúde, Programa Nacional de DST e AIDS. Manual de controle doenças sexualmente transmissíveis, Série Manuais, 68, Ministério da Saúde, Brasília, Brazil, 4th edition, 2006.

[4] R. Passini Jr., R. P. Tedesco, S. T. Marba et al., "Brazilian multicenter study on prevalence of preterm birth and associated factors," BMC Pregnancy and Childbirth, vol. 10, article 22, 2010.

[5] P.-G. Larsson, L. Fåhraeus, B. Carlsson, T. Jakobsson, and U. Forsum, "Predisposing factors for bacterial vaginosis, treatment efficacy and pregnancy outcome among term deliveries; results from a preterm delivery study," BMC Women's Health, vol. 7, article 20, 2007.

[6] B. J. Acobsson, P. P. Ernevi, L. C. Hidekel, and J. J, "Bacterial vaginosis in early pregnancy may predispose for preterm birth and postpartum endometritis," Acta Obstetricia et Gynecologica Scandinavica, vol. 81, no. 11, pp. 1006-1010, 2002.

[7] Department of Reproductive Health and Research, World Health Organization, "Guidelines for the management of sexually transmitted infections," 2012, http://www.who.int/hiv/pub/ sti/en/.

[8] S. Mullick, D. Watson-Jones, M. Beksinska, and D. Mabey, "Sexually transmitted infections in pregnancy: prevalence, impact on pregnancy outcomes, and approach to treatment in developing countries," Sexually Transmitted Infections, vol. 81, no. 4, pp. 294-302, 2005.

[9] M. Becker, J. Stephen, S. Moses et al., "Etiology and determinants of sexually transmitted infections in Karnataka state,
South India," Sexually Transmitted Diseases, vol. 37, no. 3, pp. 159-164, 2010.

[10] L. M. Niccolai, K. A. Ethier, T. S. Kershaw, J. B. Lewis, and J. R. Ickovics, "Pregnant adolescents at risk: sexual behaviors and sexually transmitted disease prevalence," American Journal of Obstetrics and Gynecology, vol. 188, no. 1, pp. 63-70, 2003.

[11] K. A. Apea-Kubi, S. Yamaguchi, B. Sakyi, T. Kisimoto, D. OforiAdjei, and T. Hagiwara, "Neisseria gonorrhoea, Chlamydia trachomatis, and Treponema pallidum infection in antenatal and gynecological patients at Korle-Bu Teaching Hospital, Ghana," Japanese Journal of Infectious Diseases, vol. 57, no. 6, pp. 253-256, 2004.

[12] M. A. S. Fernandes, D. G. Antonio, L. G. Bahamondes, and C. V. Cupertino, "Conhecimento, atitudes e práticas de mulheres brasileiras atendidas pela rede básica de saúde com relação às doenças de transmissão sexual," Cadernos de Saúde Pública, vol. 16, supplement 1, pp. 103-112, 2000.

[13] Ministério da Saúde. Secretaria de Vigilância em Saúde. Programa Nacional de DST e Aids, Pesquisa de conhecimento, atitudes e práticas na população brasileira de 15 a 54 anos, Ministério da Saúde, Brasília, 2006.

[14] Fundação de Economia e Estatística (FEE) Siegfried Emanuel Heuser, 2013, http://www.fee.tche.br/sitefee/pt/content/resumo /pg_municipios_detalhe.php?municipio=Rio+Grande.

[15] J. L. Kelsey, A. S. Whittemore, A. S. Evans, and W. D. Thompson, Methods in Observational Epidemiology, Oxford University Press, New York, NY, USA, 2nd edition, 1996.

[16] A. J. D. Barros and V. N. Hirakata, "Alternatives for logistic regression in cross-sectional studies: an empirical comparison of models that directly estimate the prevalence ratio," $B M C$ Medical Research Methodology, vol. 3, article 21, 2003.

[17] T. M. V. Fonseca, J. A. Cesar, A. A. Hackenhaar, E. F. Ulmi, and N. A. Neumann, "Corrimento vaginal referido entre gestantes em localidade urbana no Sul do Brasil: prevalência e fatores associados," Cadernos de Saúde Pública, vol. 24, pp. 558-566, 2008.

[18] J. A. Cesar, R. A. Mendoza-Sassi, D. A. González-Chica et al., "Prevalência e fatores associados à percepção de ocorrência de corrimento vaginal patológico entre gestantes," Cadernos de Saúde Pública, vol. 25, pp. 2705-2714, 2009.

[19] X.-S. Chen, Y.-P. Yin, L.-P. Chen et al., "Sexually transmitted infections among pregnant women attending an antenatal clinic in Fuzhou, China," Sexually Transmitted Diseases, vol. 33, no. 5, pp. 296-301, 2006.

[20] M. A. L. Araújo, J. S. N. F. Bucher, and P. Y. Bello, "Eficácia do aconselhamento para doenças sexualmente transmissíveis em unidades de referência da cidade de Fortaleza, CE, Brasil," Jornal Brasileiro de Doenças Sexualmente Transmissíveis, vol. 16, pp. 3137, 2004.

[21] D. S. Correia, L. V. A. Santos, A. M. N. Calheiros, and M. J. Vieira, “. Adolescentes grávidas: sinais, sintomas, intercorrências e presença de estresse," Revista Gaúcha de Enfermagem, vol. 32, pp. 40-47, 2011.

[22] V. Patel, B. R. Kirkwood, S. Pednekar, H. Weiss, and D. Mabey, "Risk factors for common mental disorders in women: population-based longitudinal study," British Journal of Psychiatry, vol. 189, pp. 547-555, 2006.

[23] M. A. Ayoya, G. M. Spiekermann-Brouwer, A. K. Traoré, R. J. Stoltzfus, and C. Garza, "Determinants of anemia among pregnant women in Mali," Food and Nutrition Bulletin, vol. 27, no. 1, pp. 3-11, 2006. 
[24] L. F. Cram, M.-I. Zapata, E. C. Toy, and B. Baker III, "Genitourinary infections and their association with preterm labor," American Family Physician, vol. 65, no. 2, pp. 241-248, 2002.

[25] M. F. da Silveira, I. S. Santos, A. J. D. Barros, A. Matijasevich, F. C. Barros, and C. G. Victora, "Increase in preterm births in Brazil: review of population-based studies," Revista de Saude Publica, vol. 42, no. 5, pp. 957-964, 2008.

[26] G. J. Lajos, R. Passini Jr., M. L. Nomura et al., "Cervical bacterial colonization in women with preterm labor or premature rupture of membranes," Revista Brasileira de Ginecologia e Obstetricia, vol. 30, no. 8, pp. 393-399, 2008. 


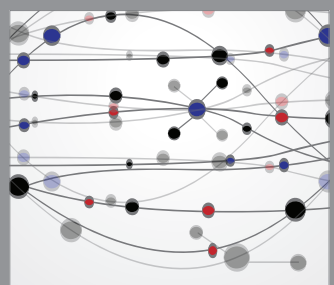

The Scientific World Journal
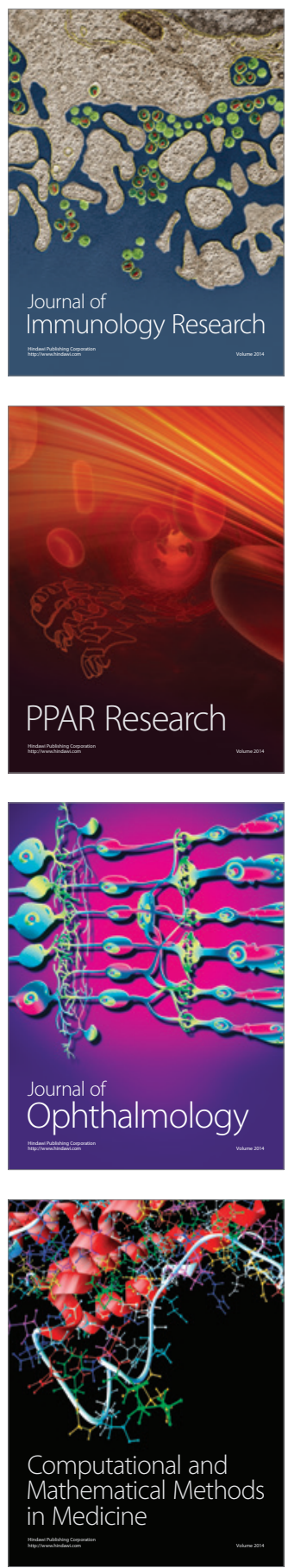

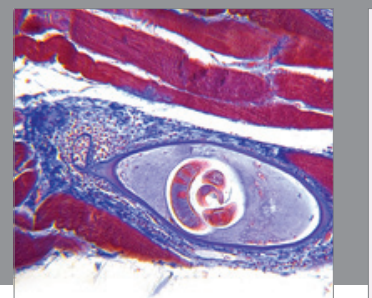

Gastroenterology

Research and Practice
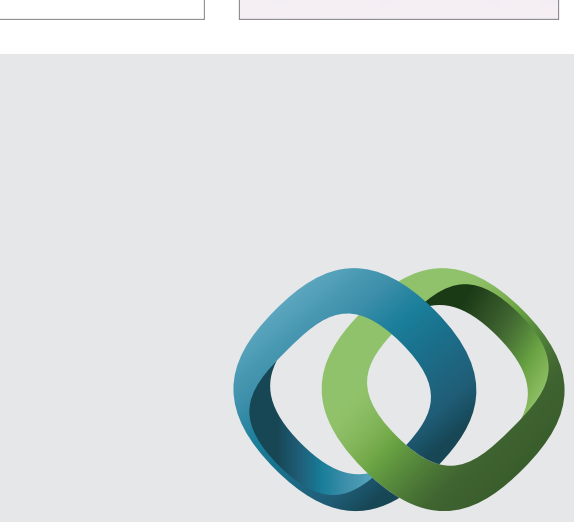

\section{Hindawi}

Submit your manuscripts at

http://www.hindawi.com
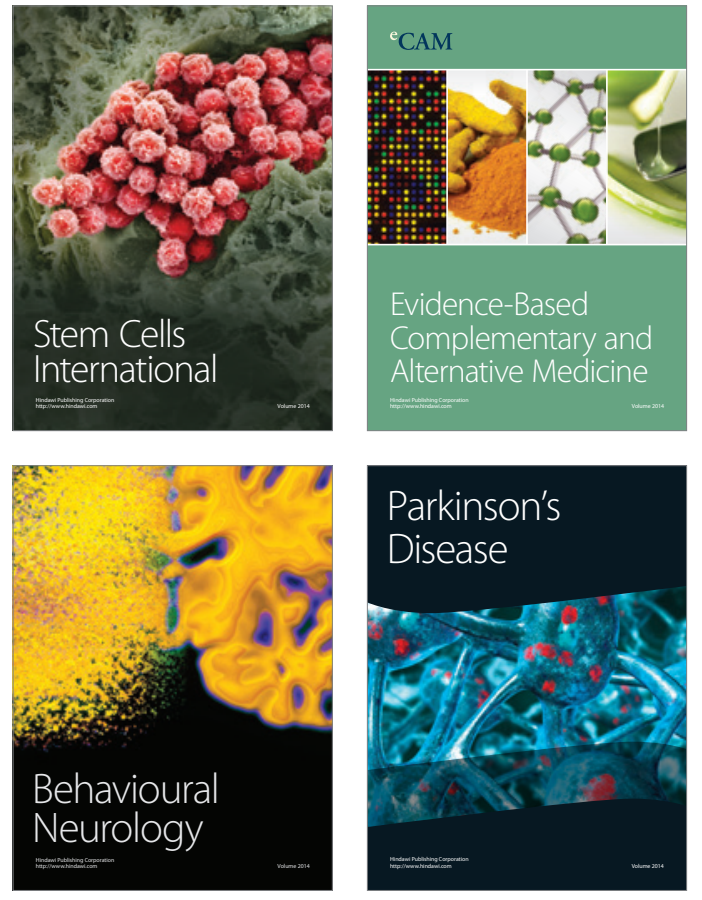
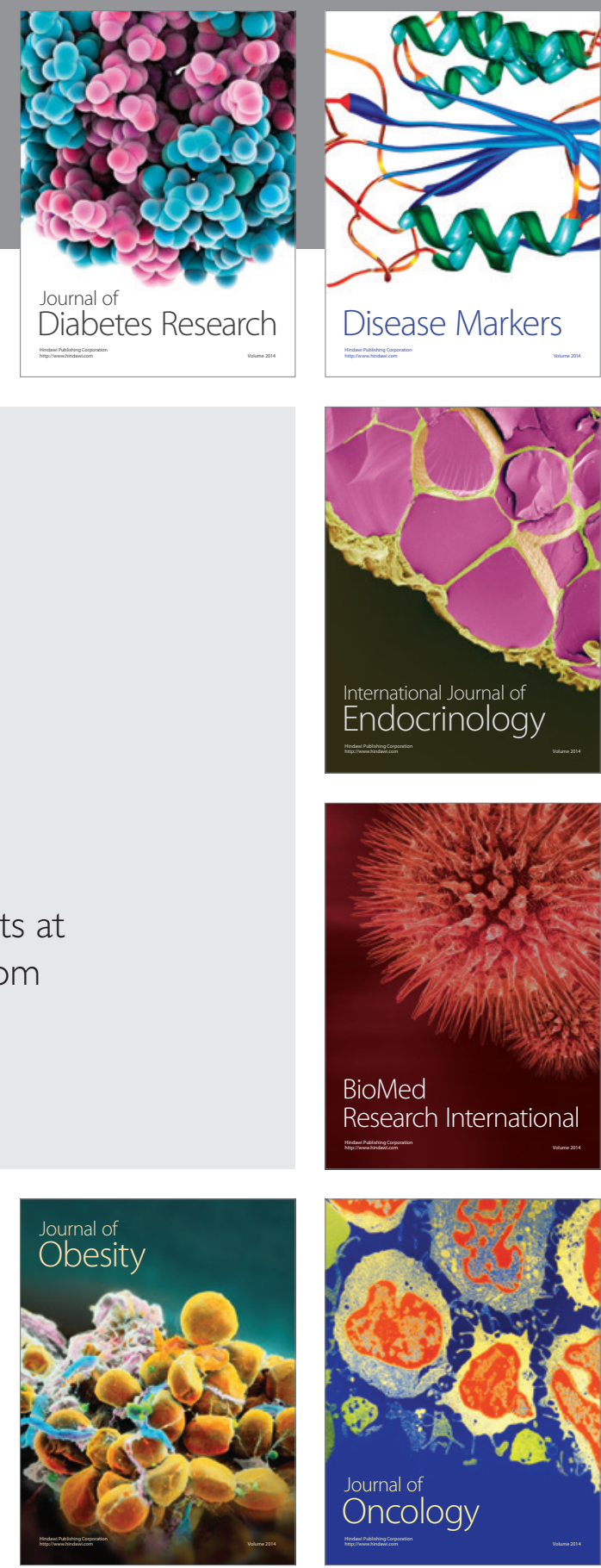

Disease Markers
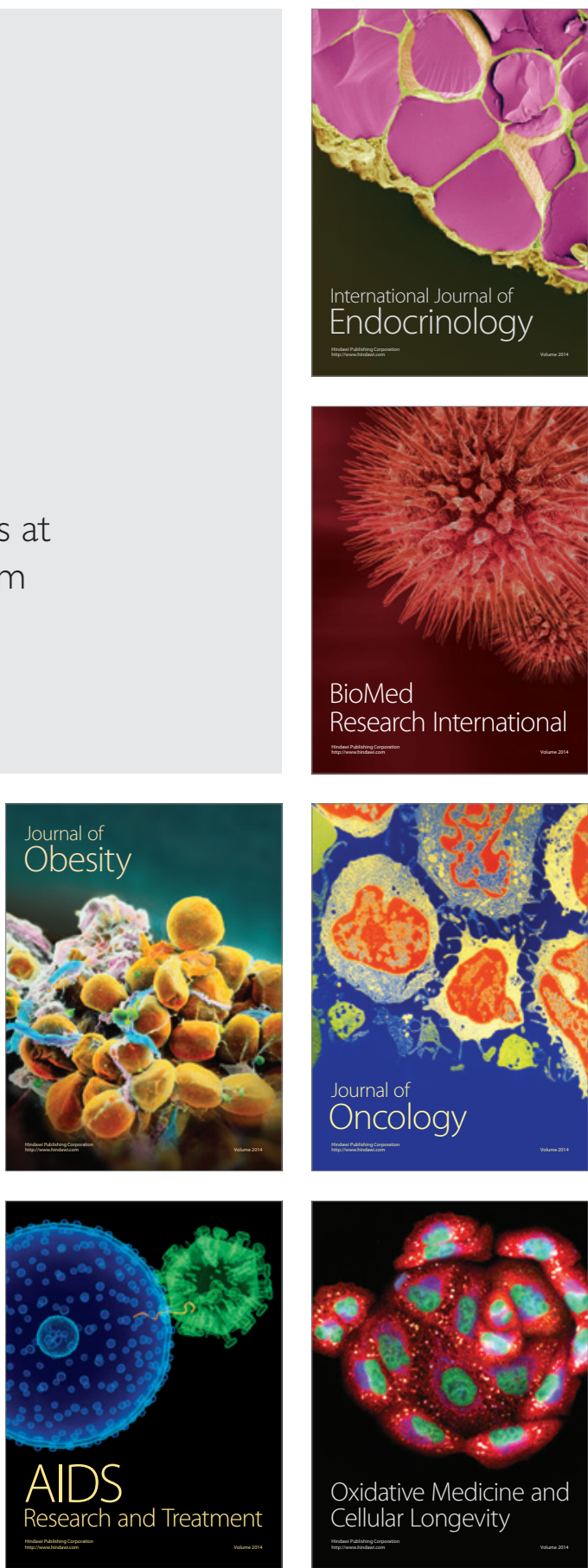